International Journal of Advanced Academic Research | ISSN: 2488-9849

Vol. 7, Issue 3 (March, 2021) | www.ijaar.org

Journal DOI: www.doi.org/10.46654/ij.24889849

\title{
TRUCE MISSIONS, NON-VIOLENT CAMPAIGNS AND PEACEFUL RESOLUTIONS OF CONFLICTS: LESSONS FROM THE ACTIVITIES OF PEACE DIRECT CHARITY ORGANISATION IN NORTHERN NIGERIA
}

\author{
Dr. Temitope Francis Abiodun \\ Department of Peace, Security and Humanitarian Studies \\ Faculty of Multidisciplinary Studies \\ University of Ibadan, Ibadan, Nigeria \\ E-mail: tf.abiodun@ui.edu.ng \\ Marcus Temitayo Akinlade \\ Department of Political Science and International Diplomacy \\ School of Social and Management Sciences \\ Bamidele Olumilua University of Education, Science and Technology, \\ Ikere-Ekiti, Nigeria \\ Dr. Olanrewaju Lateef Yusuf \\ Department of Peace, Security and Humanitarian Studies \\ Faculty of Multidisciplinary Studies \\ University of Ibadan, Ibadan, Nigeria
}

\begin{abstract}
Among the major threats halting the wheel of developments in northern Nigeria is the rising spate of insecurity and conflicts that have now assumed various formidable dimensions in all ramifications. The waves of violence and armed conflicts have continued to take toll on the region over the last three decades, claimed over twenty-eight thousand $(28,000)$ lives and got three million (3 million) people displaced. Despite the disheartening statistics, Peace Direct (PD), a charitable organization known for its non-violent and peace building initiatives, and having supported the civil societies in conflict zones for over a decade across the globe, has now come out optimistic that a non-violent and peaceful northern Nigeria is possible. The study examines the various instances and factors giving birth to insecurity and violence in northern Nigeria; and also the activities of Peace Direct Charity Commission (PDCC) towards ensuring truce brokerage missions, non-violent campaigns and peaceful resolutions of conflicts in the region. The study adopts a democratic peace theory to explain the need for war's absence in peaceful settings as the paper relies on both primary and secondary sources of data with significant reliability index. The study, however, reveals the various factors aiding insecurity and violence in the region to be; a disconnect between the people and government, abject poverty, increased rate of unemployment, weak and poorly funded military establishments, interagency rivalry, low-level of intelligence gathering on the part of security agencies in Nigeria, among others. Therefore, making the region to be non-violent and peaceful; the Nigerian security agencies, social system, public institutions truce brokerage missions, and peace building efforts or initiatives must be adequately strengthened.
\end{abstract}

Keywords: Peace Direct Charity Organization, Truce missions, Non-violent campaigns, Peace movement, Northern Nigeria, Security. 
Journal DOI: www.doi.org/10.46654/ij.24889849

\section{Introduction}

For over two decades now, Nigeria has been engulfed in insecurity resulting to numerous deaths of innocent civilians, foreigners, some members of the nation's security personnel, elected officials and many government workers. And it is no more news that Northern Nigeria continues to suffer from waves of violence and armed conflict, the varied symptoms of varied causes (Abiodun, 2016). The insecurity problem has assumed various dimensions thereby making the country's political and economic managers and, the entire nation, to rue the loss of their loved ones, and absence of safety in most parts of the country. The rate of crimes; kidnappings, ritual killings, suicide bombings, religious killings, politically-motivated killing, ethnic conflicts, armed banditry amongst others has increasingly posed dangerous threat to human lives and national security. There has also been strong advocacy for a multi-stakeholder approach to the security solution rather than concentrating heavily on only military options (Imhonopi and Urim, 2013), but the problem seems to have defied several attempts. This fact may not be unconnected with the growing ethnic intolerance, religious bigotry, political rivalry and a large number of citizens in the country who have felt short-changed and not given attention (Abiodun, 2016).

That is the reason Abiodun (2016) made an observation when he submitted that the primordial tendencies of various ethnic nationalities towards violence, the perennial upsurge of militias and religious extremism in place, given a look by some dominant religious groups in Nigeria, have inevitably worsened the spate of insecurity and enlarged its scope. Not only has the continued state of insecurity in Nigeria and most especially in northern region posed dangerous threats to the fabric of national integration and brought about the ecology of fear, disquiet and anxiety, it has also unleashed a fatal blow to industrial development respectively (Abiodun, 2020). The destruction of the needed infrastructural facilities has taken the state many years backwards. The state has continued to struggle in the face of these daring vicissitudes and continued to evolve strategies to douse the tension (Emuedo, 2014). The situation, however, spurred Amnesty International in 2015 to reveal that over 2 million people had been displaced by the conflict between the military and the armed group Boko Haram (Amnesty International, 2015).

Despite the sobering statistics, peace-building organisations in Northern Nigeria are optimistic that a more peaceful future remains a possibility. Peace Direct has more than a decade of experience successfully supporting civil society in conflict zones around the world. In July 2016, Peace Direct convened and consulted with a range of local peace-building organizations working in northern Nigeria, Kano State and others states in the country (Peace Direct Annual Report, 2018). The group runs a range of projects and programmes to respond to, mitigate and ultimately prevent atrocities and violent conflict in their communities. However, in order to make that peaceful future a reality, peace-building efforts must be strengthened. This study highlights civil society analysis of the main conflict issues in northern Nigeria - and what can be done to address them (Igbuzorr, 2011). It also provides an overview of key causes of violence, and the strategies that local peace-builders adopt toward building lasting peace in the region. It is however noted in particular that Boko Haram is not the only threat raving the region; this is sequel to the fact that there is a tendency to associate northern Nigeria solely with the violence of Boko Haram (Lester, and Jennifer, 1999). In fact, a wide range of conflicts and issues affect the region; and only through a more nuanced understanding of these issues, and how they have spearheaded a rise to terrorism as well as other violence, would peace builders and their partners be able to address them. Also, more attention needs be a focused on youth engagement in the region because the challenge that is as well common to many conflict issues in northern Nigeria is not finding 
Journal DOI: www.doi.org/10.46654/ij.24889849

Article DOI: www.doi.org/10.46654/ij.24889849.s7326

productive ways to support young people, and as well as victims or survivors of conflict - this often breeds violence (Abiodun, 2020).

For years, the use of a nonviolent action campaign has been featured prominently in political life. There is an astronomical increase in its use in recent times by several movements, leading to significant socio-political reforms or social change. Though many nonviolent movements emphasized overthrowing repressive governments (Martin, 2015:537), there are a number of others whose focus were on other aspects of social change, including influencing government policies. The attention on nonviolence in this paper is not unconnected to the view of the most effective method available in the circumstances (Weber, 2003) and in the principled or ideological non-violence viewpoints of Mahatma Gandhi and Martin Luther King Jr. that seek to deal with the causes, rather than the symptoms of the problem in question (Pandey, 1998). The rationale for the use of nonviolence largely rests on the joint conviction that it works instrumentally and that it is ethical.

Also as a weapon, non-violence is accessible to all and does not seek to alienate the opponent, including the third party. Thus, it can be used to bring everyone on board (Sagård, 2019). It has the potential to end cycles of violence and counter-violence, open windows of opportunity for conversion, and can draw media focus on the issue at stake, as well as often producing a constructive outcome. It is against this backdrop that this paper seeks to explore the various instances and factors giving birth to insecurity and violence in northeast Nigeria; activities of Peace Direct (PD) towards ensuring and attaining; truce brokerage missions, non-violent campaigns and peaceful resolution of conflicts in the region. The study in addition discusses these issues in light of the views of local peace builders, and the strategies they suggest need to be prioritized in order to address them; while it is important to address all of the factors relating to conflict in Northern Nigeria, Peace Direct Charity Commission also focused on developing initial strategies for the three areas they consider to be critical: socio-economic conflict, interreligious conflict, and violent extremism.

\section{Conceptual Clarifications}

\section{Concept of Non-violent Campaigns}

The concept of nonviolence speaks of the personal practice of being harmless to one's self and others under every condition. It may come from the belief that hurting people, animals and/or the environment is unnecessary to achieve an outcome and it may refer to a general philosophy of abstention from violence (Ackerman and Jack, 2001). It may be based on moral, religious or spiritual principles, but also the reasons for it may be purely strategic or pragmatic. Nonviolence has "active" or "activist" elements, in that believers generally accept the need for nonviolence as a means to achieve political and social change (Graham, 2009). Thus, for instance, Tolstoyan and Gandhism posit that non violence is both a philosophy and strategy for social change that rejects the use of violence, but at the same time it sees nonviolent action (also called civil resistance) as an alternative to passive acceptance of oppression or armed struggle against it (Ives, 2001). In general, advocates of an activist philosophy of nonviolence use diverse methods in their campaigns for social change, including critical forms of education and persuasion, mass noncooperation, civil disobedience, nonviolent direct action, and social, political, cultural and economic forms of intervention (James, 1989). 
Journal DOI: www.doi.org/10.46654/ij.24889849

In modern times, nonviolent campaigns have remained a powerful tool for social protest and revolutionary social and political change (Lester and Jennifer, 1999). There are many examples of their use. However, certain movements were particularly influenced by a philosophy of nonviolence and they include Mahatma Gandhi's leadership style of a successful nonviolent struggle against British rule in India, Martin Luther King Jr.'s and James Bevel's adoption of Gandhi's nonviolent methods in their campaigns to win civil rights for African Americans; and César Chávez's campaigns of nonviolence in the 1960s to protest the treatment of farm workers in California among others (Pandey, 1998). The concept "non-violence campaign" is often linked with peace or it is used as a synonym for it, and despite the fact that it is frequently equated with passivity and pacifism, this equation is rejected by nonviolent advocates and activists (Kurlansky, 2008).

Nonviolence specifically refers to the absence of violence and it is always the choice to do no harm or the choice to do the least amount of harm, and passivity is the choice to do nothing. Sometimes nonviolence is passive, and other times it is not (Roberts, 2009). For example, if a house is burning down with mice or insects in it, the most harmless appropriate action is to put the fire out, not to sit by and passively let the fire burn. At times there is confusion and contradiction about nonviolence, harmlessness and passivity. A confused person may advocate nonviolence in a specific context while advocating violence in other contexts (Stanley and Richard, 2005). For example, someone who passionately opposes abortion or meat eating may concurrently advocate violence to kill an abortionist or attack a slaughterhouse, which makes that person a violent person. Nonviolence is a powerful and just weapon. Indeed, it is a weapon that remains unique in history; it cuts without wounding and ennobles the man who wields it (Ronald and Neil, 1999).

Moreover, Nagler Michael (2017) submits there are existing six (6) principles and guidelines that aid execution of nonviolent campaigns more safely and effectively in a society as follows:

i. Respect everyone-including yourself: The more we respect others, the more effectively we can persuade them to change. Never use humiliation as a tool-or accept humiliation from others, as that only degrades everyone. Remember, no one can degrade you without your permission.

ii. Always include constructive alternatives: Concrete action is always more powerful than mere symbolism, especially when that action creates constructive alternatives: setting up schools, forming cottage industries, establishing farming cooperatives, devising community-friendly banking.

iii. $\quad$ Be aware of the long term: Nonviolent action always has positive results, sometimes more than we intended. Have clear goals. Cling to essentials (like human dignity) and be clear about your principles, but be ready to change tactics or compromise on anything else.

iv. Look for win-win solutions: You are trying to rebuild relationships rather than score "victories." In a conflict, we can feel that in order for one side to win the other must lose, which is not true. Therefore, we do not seek to be winners or rise over others; we seek to learn and make things better for all.

v. Use power carefully: We are conditioned, especially in the West, to think that power "grows out of the barrel of a gun." There is indeed a kind of power that comes from threats and brute force-but it is powerless if we refuse to comply with it.

vi. Claim our legacy: Nonviolence no longer needs to take place in a vacuum. Always note that if you are using nonviolence with courage, determination and a clear 
strategy, you will more than likely succeed: win or lose, you will be playing your part in a great transformation of human relationships that our future depends on (Nagler, 2017).

In addition, the various advocates of nonviolent action believe there should be absolute cooperation and consent which form the roots of civil or political power. Therefore, all reigns or rules; including bureaucratic institutions, financial institutions, and the armed segments of society (such as the military and police); usually depend on level of compliance from citizens (Stanley and Richard, 2005). Also on a national level, the strategy of nonviolent action seeks to undermine the power of rulers by encouraging people to withdraw their consent and cooperation. The forms of nonviolence draw inspiration from both religious or ethical beliefs and political analysis (Anderson, 2000). Thus, religious or ethically-based nonviolence is sometimes seen to be principled, philosophical, or ethical nonviolence, while nonviolence campaigns based on political analysis is often referred to be: tactical, strategic, or pragmatic nonviolent action (Stanley and Richard, 2005). Therefore, most of discussed dimensions seem to be present within the thinking of particular movements or individuals.

\section{Concept of Truce missions}

The concept of truce (or ceasefire) defined to be a temporary stoppage of a war in which both parties and sides agree with each other to suspend all ongoing aggressive actions in a state (Wilson, 2016). The concept of truce, historically, is believed to have been in existence during the Middle Ages, when it was actually described or called a 'truce of God'. However, the truce or ceasefire can be confirmed as a humanitarian gesture, it could be preliminary when, made prior to a political agreement, or definitive when made with the intention of resolving a conflict (Brockell, 2017). The concept may be declared as part of a formal treaty that is signed, and has also been described to be part of an informal agreement between opposing forces in a conflict. The concept of truce or ceasefires may take place between state actors and when the stage of a war or conflict stoppage is reached, and it may even involve non-state actors or 'locals'. Truce may be formal or written, or informal; and the conditions laid down are made to be public or secret (Wilson, 2016). Truce may occur through mediation or otherwise as part of a peace process and it could be directed by United Nations Security Council resolutions, Chapter VII of the United Nations Charter (Evans, Bartollas, Graham, and Henke, 2011).

In the same vein, a truce is also narrower than armistice that appears broader, and it refers to basically a formal agreement to end fighting or conflict in a state (Brockell, 2017). Truce of ceasefires may be abused by parties involved as cover to reposition their forces. Various instances of truce have emerged in recent times during: the World War 1 and it was known as 'Christmas truce'. During the war on December 24, 1914, there was an unofficial truce or ceasefire on the Western Front as France, the United Kingdom, and Germany observed Christmas (Fortna, 2018). There are accounts that claimed the unofficial ceasefire took place throughout the week leading to Christmas, and that British and German troops exchanged seasonal greetings and songs between their trenches; also experienced during the Korean War in November 29, 1952, the US President-elect, Dwight D. Eisenhower, was in Korea to see how to put an end to the war. And With the United Nation's acceptance of proposed truce from India, the Korean People's Army (KPA), the People's Volunteer Army (PVA), and the UN Command had the battle halted (Hay, 1990).

Moreover during the Gulf War after Iraq was driven out of Kuwait by the US-led coalition forces while on Operation Desert Storm, Iraq and the UN Security Council signed a truce or ceasefire 
agreement on March 3, 1991 (Forster, 2019). Also during the Kashmir conflict which is IndoPakistani War of 1947-1948 and UN mediation of the Kashmir dispute, a United Nation-based truce was agreed between India and Pakistan, on 1 January 1949, ending the prolonged war. Other instances of truce were experienced during the Israeli-Palestinian conflict; Syrian Civil War known as 'Syrian peace process' (Sagård, 2019). And lastly the 2020 global truce or ceasefire witnessed following the response to a formal appeal by United Nations SecretaryGeneral, António Guterres on March 23 for a global ceasefire as part of the United Nations' response to the COVID-19 pandemic. And on 24 June, 2020, 170 United Nation Member States and Observers, however, signed a non-binding statement in support of the appeal, increased to 172 on 25 June, 2020, while on $1^{\text {st }}$ of July 2020, the United Nations Security Council finally passed a resolution demanding a general and immediate global cessation of hostilities for at least ninety days (Sosnowski, 2020).

\section{Theoretical Framework}

The study is explained through a Democratic Peace Theory.

The democratic peace theory posits that democracies are hesitant to engage in armed conflict with other identified democracies. The theory was proposed by and espoused in the works of philosopher, Immanuel Kant, (Perpetual Peace: A Philosophical Sketch) in 1795, and political theorist, Thomas Paine, (Common Sense) written in 1776 respectively (Uriel, 2015). The theory of democratic peace was not rigorously or scientifically studied until the 1960s, and the basic principles of the theory had been argued as early as the 1700s in the works of Immanuel Kant and Thomas Paine. It becomes notable that Kant's theory on the concept was that a majority of the people would never vote to go to war, unless in self-defense (Paine, 1945). Therefore, if all nations were republics, it would end war, because there would be no aggressors; while Thomas Paine however made stronger claims about the peaceful nature of republics. He (Paine) wrote in his work "Common Sense" in 1776 that the Republics of Europe are all and could be said to always remain in peace. Thomas Paine in the same vein argues that kings would go to war out of pride in situations where republics would not (Levy and Thompson 2011; Paine 1945:27). In addition to this, a French historian and social scientist, Alexis de Tocqueville, submits in his work (Democracy in America: 1835-1840) that, democratic nations were less likely to wage war.

However among proponents of the democratic peace theory, several factors are discovered and held as highly motivating and they include the submissions that: democratic leaders are forced to accept responsibility for war losses to a voting public; publicly accountable states people are open to launch diplomatic institutions for resolving international tensions; democracies are not liable to view states with adjoining policy and governing doctrine as hostile; and democracies tend to possess greater public wealth than other states, and therefore eschew war to preserve infrastructure and resources respectively (Beck, King, Zeng, 2004). The theory is often criticized on grounds that it conflates correlation with causation, and that the academic definitions of 'democracy' and 'war' can be manipulated so as to manufacture an artificial pattern (Pugh, 2005). In the same vein, Melvin Small and David Singer (1976) argue an absence of wars between democratic states is found with two marginal exceptions, and denied the trend pattern is endowed with statistical significance; while (Bennett, 2006); and Bremer, 1993) submit that there is significant correlation between democracy and peacefulness after controlling for many possible confounding variables.

\section{Methodology}


The study employed both the exploratory and descriptive research designs. This research was conducted based on a consultation, also referred to by local peace-building practitioners held in November in 2020 in Adamawa, Plateau, Kano and other northern states across the northern region of Nigeria. Data were sourced from primary (In-depth interviews and administration of questionnaire) from the selected respondents respectively. Prior to the study, the researcher purposively sampled the various communities that immensely contributed to the background research; 226 respondents were selected from 10 states across Northern Nigeria and were interviewed, the results of which were summarized below and fed into the report. Data were also sourced using the secondary sources which include (books, Peace Direct Annual Reports, newspapers and bulletins, reports on intelligence, surveillance and security). The instruments adopted were validated and results were content analyzed.

\section{Respondents' Data}

\begin{tabular}{|l|l|l|l|}
\hline Serial No. & Response & Frequency & Percentage \% \\
\hline 1. & Male & 136 & 59.88 \\
\hline 2. & Female & 90 & 40.12 \\
& Total & 226 & $100 \%$ \\
\hline \multicolumn{5}{|l|}{ Age } & Percentage \% \\
\hline Serial No. & Response & Frequency & 39.82 \\
\hline 1. & $18-30$ & 95 & 22.12 \\
\hline 2. & $31-45$ & 55 & 21.68 \\
\hline 3. & $46-55$ & 59 & 2.7 \\
\hline 4. & 56 and Above & 12 & $100 \%$ \\
\hline & Total & 226 & \\
\hline
\end{tabular}

\begin{tabular}{|l|l|l|l|}
\hline \multicolumn{4}{|c|}{ Marital Status } \\
\hline Serial No. & Response & Frequency & Percentage \% \\
\hline 1. & Single & 58 & 25.6 \\
\hline 2. & Married & 100 & 44.2 \\
\hline 3. & Divorced & 12 & 5.3 \\
\hline 4. & Widow & 26 & 11.5 \\
5. & Widower & 30 & 13.4 \\
\hline & Total & 226 & $100 \%$ \\
\hline
\end{tabular}

\begin{tabular}{|l|l|l|l|}
\hline \multicolumn{4}{|c|}{ Academic Qualifications } \\
\hline Serial No. & Response & Frequency & Percentage \% \\
\hline 1. & No Formal Education & 58 & 25.6 \\
\hline 2. & SSCE & 100 & 44.2 \\
\hline 3. & NCE/OND/Equivalent & 12 & 5.3 \\
\hline 4. & B. Sc/HND & 30 & 13.4 \\
5. & Masters/PhD & 26 & 11.5 \\
\hline & Total & 226 & $100 \%$ \\
\hline
\end{tabular}

Selected States in the North

\begin{tabular}{|l|l|l|l|}
\hline Serial No. & Response & Frequency & Percentage \% \\
\hline 1. & Adamawa & 22 & 9.7 \\
\hline 2. & Yobe & 21 & 9.2 \\
3. & Kano & 16 & 7.1 \\
\hline
\end{tabular}


Journal DOI: www.doi.org/10.46654/ij.24889849

Article DOI: www.doi.org/10.46654/ij.24889849.s7326

\begin{tabular}{|l|l|l|l|}
\hline \hline 4. & Plateau & 48 & 21.2 \\
\hline 5. & Kogi & 36 & 15.9 \\
\hline 6. & Katsina & 15 & 6.6 \\
7. & Bornu & 10 & 4.4 \\
\hline 8. & Kebbi & 22 & 9.7 \\
\hline 9. & Taraba & 17 & 7.5 \\
\hline 10 & Sokoto & 19 & 8.7 \\
\hline & Total & 226 & $100 \%$ \\
\hline
\end{tabular}

Source: Field Survey, 2020.

\section{Discussion of Findings}

\section{Overview of the Selected Security Threats and Instances of Insecurity in Nigeria}

An avalanche of literature have elaborated case studies of insecurity in Nigeria from different informed prisms; though this study would not duplicate such efforts but rather sieve out the selected cases. These security challenges have been briefly highlighted as follows:

a. The Boko Haram Terror: This is another major insecurity threatening Nigerian existence and has negatively affected the nation's economy. According to Abiodun (2016), the word "Boko Haram" means western education if forbidden. The Boko Haram is a controversial Nigerian militant Islamist group that has sought to impose Sharia law or its radical interpretation of Islam on the northern states of Nigeria and then to other parts of the country. It is rightly affirmed that the group opposes not only western education, but also Western culture and modern science. The group has claimed thousands of Nigerians' lives and lots of valuable property looted and destroyed (Abiodun, 2016).

b. Assassinations by Fulani Herdsmen and kidnapping for ransom: There is high rate of herdsmen killings in the state at present, no one is safe. The study is not carried out to reveal the disgusting cruel butcher of human lives in northern states arising from the farmers-herdsmen crisis; kidnapping and killings in Nigeria, but it is necessary to also report the recent losses of human lives from kidnapping and killings by Fulani herdsmen (Research Survey, 2020). Victims are on daily basis kidnapped for ransom.

c. The Niger Delta Imbroglio: According to Emuedo (2014), the Niger Delta conflict came up in the early 1990s as a result of tensions between international oil companies (IOCs) and some community representatives of the region who felt they were being exploited without due compensation from the oil companies. Following this, agitations continued in the region during the period and persisted till date. However, competition for oil wealth in the region gave rise to agitations, violence and subsequent extra-judicial killing which led to demise of Ken Saro-Wiwa and other nine (9) Ogoni leaders during General Sanni Abacha junta (Research Survey, 2020). The killing was condemned both within the country and international community and was followed by sanctions placed on Nigerian state at that particular period. Thus, the foundation was laid for the wave of insecurity that beleaguered the entire region and spread throughout the tentacles of power. There are environmental degradation and the absolute poverty, and as a result, the region has witnessed severe security threats and the emergence of other agitating groups affiliated to the Niger Delta Avengers (NDA); Movement for the Emancipation of the Niger Delta (MEND) like the Niger Delta People's Volunteer Force (NDPVF); and the Niger Delta vigilante (NDV) (Abiodun, 2020). 
d. Conflicts with ethno-religious colourations: Ethno-religious conflicts have been identified as a source of insecurity in Nigeria (Igbuzor, 2011). These ethno-religious conflicts assume various dimensions when the social relations between members of one ethnic or religious group and another of such group in a multiethnic and multi-religious society is characterized by lack of cordiality, mutual suspicion and fear, and a tendency towards violent confrontations to settle grievances (Research Survey, 2020).

\section{Overview of the Conflicts and Insecurity Issues in Northern Nigeria}

From the research survey, it is highlighted that a range of conflict issues that affect Northern Nigeria. These include disputes and violence related to:

i. Religious conflicts motivated by or in the name of religion, within and between different faiths

ii. Violent extremism, defined by participants in this report as 'the attempt to enforce an extreme interpretation of religious issues through the use of violence.'

iii. Socio-economic issues, in particular poverty and inequality.

iv. Politically-driven violence, notably related to corruption.

v. Ethnic and inter-communal violence, driven by political patronage and distribution of economic benefits to certain groups over others, as well as farmer-herder disputes.

vi. Human rights violations and gender-based violence, committed by multiple parties and a cause and effect linked to all other issues.

2020).

vii. Land ownership and access to and the use of natural resources (Research Survey,

The study therefore discusses these issues in light of the views of local peace builders, and the strategies they suggest need to be prioritized in order to address them. While it is important to address all of the factors relating to conflict in Northern Nigeria, Peace Direct Charity Commission also focused on developing initial strategies for the three areas they consider to be critical: socio-economic conflict, inter-religious conflict, and violent extremism.

\section{Overview of Activities Undertaken by the Peace Direct Charity Commission (PDCC) in Northern Nigeria}

Peace Direct is an international charity organization that is dedicated to supporting local people to stop war and build lasting peace in some of the world's most fragile states. As the world is battling war and violence, touches and destroys lives from Paris to Peshawar, Mali to Yemen among others, and deadly conflict tears across communities around the world; Peace Direct Charity Commission (PDCC) wades in and its presence well felt in all ramifications (Peace Direct Annual Report, 2018). Peace Direct is also an award-winning, foreign NGO supporting local people in some of the challenging conflict environments globally. The Commission is being headed by Dylan Mathews as the Chief Executive and Office headquartered in London, United Kingdom though have offices in Washington District of Columbia and New York. The 
Journal DOI: www.doi.org/10.46654/ij.24889849

Organization became founded and registered on 18 March, 2008 in the street of London by; Priscilla Mary Elworthy, Ms Ruth Jenkins, Mr. Eliot Lyne, Ms Joan Link, Rev, Nicholas Bradbury, Mr. Dylan Mathews, Ms. Vesna Matovic, and Mr. Andres Ilves as Trustees respectively (Peace Direct Annual Report, 2018).

Led by local people in war-torn or conflict communities, Peace Direct Charity tackles all causes of violence at the root, and as well rebuild lives after war has torn communities apart. The Commission is, however, dedicated to making peace a practical option, ensuring local people have the skills and resources top make it a reality. In more than 14 years, the Charity has supported various local peace-building initiatives and organizations around the world, providing vital assistance to ensure that grassroots action stopping conflict and violence continue and grow (Peace Direct Annual Report, 2019). With its local partners, the Charity has saved lives, provided paths out of violence and built better futures for thousands of people. Also as an independent organization funded by people, it can direct funds and support to where it is most urgently needed. As a result of this, Peace Direct Charity Commission can stop wars and build peace in all ramifications. As peace builders, Peace Direct places increasing importance on the use of digital technologies to sustain peace-building work in the midst of Covid-19 pandemic. It also convenes and online consultation for people across the globe to share insights and knowledge on how to capitalize on the opportunities for peace that digital technology provides (Peace Direct Annual Report, 2019).

In addition, working with inspiring individuals and communities at the centre of peace-building efforts from Somalia to the Philippines in 2019, it supported over 28,000 people to turn away from violence and building peace from the ground up (Anderson, 2000). Local peace-builders are also making peace a practical reality for thousands of people across the globe and committed to supporting them, as in the case in northeastern Nigerian states of: (Yobe, Bauch, Adamawa, Borno, Taraba, and Gombe); North Central states (Benue, FCT, Kogi, Kwara, Nasarawa, Niger, and Plateau); and North-Western region (Jigawa, Kaduna, Kano, Katsina, Kebbi, Sokoto, and Zamfara) respectively (Research Survey, 2020). Moreover, a complex web of issues cutting across society makes the numerous conflicts in Northern part of Nigeria more challenging for peace-builders to navigate. This is as the general election in May 2019 added another layer of complexity, and was marred by tension and political violence; while the Boko Haram insurgency in the Northeast snowballed into its tenth year in Nigeria. It is, therefore, within this myriad of struggles that the Peace Direct Charity Commission's partner, Peace Initiative Network (PIN) is now working with youth to address the root causes of conflict in the region; reducing recruitment to armed groups, tackling voter manipulations and assisting in dispelling all forms of suspicion and rivalry that may ensue between different ethnic and religious groups in Nigeria (Peace Direct Annual Report, 2019).

Also in 2019 through the Peace Direct Charity Commission, over 152 young people in northern Nigeria received vocational training, grants and equipment for a variety of trades, helping to grow income and business across the communities (Peace Direct Annual Report, 2019). And according to participants, having a valuable skill set was transformative in removing the financial and social incentives, thereby drawing them to armed groups; primarily boredom, and the money offered by gangs and terrorist groups to perpetuate violence. From this initiative, 18 participants then went on to train 46 others, showing how the project would also have a ripple effects for generations to come in the region. Members of the community in Kunya, one of the 
project areas in northern Nigeria, submitted that before PIN's work commenced, there was lots of violence in the region (Research Survey, 2020). It was caused by things like politics and football; always happening at the end of matches. But when PIN arrived and conducted a threeday workshop for the coaches and captains of the teams, the young people learned how to control, manage and resolve conflicts as they occurred. These coaches then went on to train other coaches from other towns in nearby areas. After this, there was absolutely no violence at football matches in any of the surrounding areas. PIN later returned and followed up with guidance on peaceful co-existence (Research Survey, 2020).

PIN's work in Kunya did not end with football, every quarter they have multi-stakeholder meetings where they discuss what to do about community issues, so violence does not flare up. Civil defence, police, vigilantes, youth leaders, and everyone in the community are all present at these meetings, creating lines of accountability downwards and upwards. It is however observed that the crux of violence has totally stopped in Kunya (Research Survey, 2020). According to a community leader, "people do not want to be shamed - PIN has created accountability mechanisms for bad behaviour, in a culture where positive image matters.

\section{Other Issues the Peace Direct Charity Addresses in Northern Nigeria}

Also in the course of the study, the researcher from the survey conducted obtained more verifiable data on other issues being addressed by Peace Direct Charity Commission in Northern Nigeria as follows:

a. Support to civil society: It carries out vital successful peace-building efforts through local civil society groups. These initiatives are particularly appreciated by host communities, because of the fact that despite the current crisis in Northern Nigeria, civil society groups remain generally able to operate openly and safely.

$\underline{b}$. Preventing conflict and tackling violence: The Organization has also strived hard in the prevention of conflict and violence in most of the northern communities (Baga, Waklek, Bukuru, Mopamoro, Gujba, Lafia and Nasarawa communities) in Nigeria through the various approaches, methods and mechanisms deployed to avoid, minimize, and contain potential violent conflict.

c. Building livelihoods: Peace Direct Charity has worked hard in providing livelihood approaches that can generally be seen to be programmatic interventions and which enhance people's income-generating capacities by increasing their assets through the provision of cash transfers, infrastructure, support services, market expansion activities and training in the communities.

d. Improving the lives of women in conflicts: The Commission has strived hard in increasing women's access and control over overall economic resources with they can improve their wellbeing in northern Nigerian communities respectively. 
e. Advocating for justice and human rights: The Group has consistently advocated and lent its voice to equality, justice and human rights programme, thereby promoting equal access to fair and independent justice to help the local populace.

f. Mapping peace and opening dialogue for peace and tolerance: all over the world, and since the beginning of time, there are a far larger number of people who are motivated by their religious beliefs to pursue peace and tolerance. Peace Direct Charity through its mapping peace project has sought to map these opposing paradigms in most northern communities in Nigeria in recent time.

g. Advocating the platform for dialogue and peace-building: The Commission in many times, has lobbied to ensure that Nigerian government enters into a dialogue with the Boko Haram insurgents in northeast Nigeria in order to give room for peace-building by shelving the terror that has claimed over 8,000 lives in the region since year 2009 to date (Research Survey, 2020).

\section{Conclusion}

Looking towards the peace-building sector, the rhetoric around local peace-building has significantly shifted since year 2015 , and there is now a far better recognition of the role that local peace-builders play in stabilizing their communities and consolidating peace, often in locations where the international community is unable to access. This very positive change is due to the advocacy efforts made by Peace Direct Organization and as well in partnership with a growing list of likeminded initiatives, in doing something that makes the nation proud. This research, however, highlights the basic understanding that local peace builders can provide, and launch significant interventions that are adjudged to be necessary to better the lots of local people in northern Nigeria. Peace Direct hopes this will be the beginning of further and more fruitful partnerships combining the skills and experience of all those who want to see peace in Northern Nigeria. With the activities and giant strides of Peace Direct in northern Nigeria, there is strong hope and optimism that peace would one day return to the region.

\section{Recommendations}

The study therefore recommends the following for peaceful co-existence in northern Nigeria:

i. There must be economic security, and provision of jobs and livelihoods by the government and stakeholders as one of their most important concerns in the region.

ii. More room be created for dialogue in the region with Nigeria government so that Boko Haram terrorists could shelve their terror.

iii. Corruption should be totally fought to the barest minimum, shunned and jettisoned by people at the helm of affairs in the country; and there should be incessant call for absence of political or election-based violence and inter-religious conflicts in the country.

vi. Youth programmes should be adequately intensified in the region for sustainable peace building in the region. 
vii. Region wide radio campaigns promoting peace and tolerance between religions.

viii. Expansion of peace clubs and interfaith activities at youth centres. These should focus on interfaith dialogue, tolerance, community development, hate and dangerous speech, women's rights and youth engagement. All the Peace Exchange participating CSOs saw the provision of training in delivering these programmes as key to supporting their work.

ix. Expansion of interfaith sporting activities, which are especially effective in engaging large numbers of young people. These usually draw large crowds and give opportunities for talks about peace building or community issues.

x. Building capacity of civil society and government officials to combat the drivers of violent conflict, and strengthen links between them to coordinate their atrocity prevention actions.

xi. Protecting and giving attentions to the victims of child marriage in the region.

xii. Governments at all levels should work together to empower women and young people to improve their lives and build peace in Nigeria, through capacity building, training for caregivers and peace education.

\section{Acknowledgement}

The researchers appreciated the inputs of members of the various bodies and respondents for their tireless efforts during the work. 


\section{References}

Abiodun, T. F. (2020). Birthing Security in an Insecure State: Possibilities of Rescuing Nigeria's Failing Security through Intelligent Leadership (Lessons from Chief Afe Babalola, SAN). In Okojie, S. and Akinyemi, R. (Eds.). Book in Honour of Chief Afe Babalola, SAN:Nigeria, ABUAD Press.

Abiodun, T.F. (2016). An Appraisal of Nigeria's Counter-Terrorism Policy: The Case of Boko Haram. In Akinwumi, F.S., and Olaniyan, D.A. (Eds.) Global Perspectives in Education. Ibadan: His Lineage Publishing House. 145-155pp. ISBN 978-978-525514-0. (Nigeria)

Ackerman, P. and Jack, D. (2001). "A Force More Powerful: A Century of Non-Violent Conflict"(Palgrave Macmillan).

Anderson, K. (2000). "The Ottawa Convention Banning Landmines: The Role of International Non-Governmental Organisations and the Idea of International Civil Society". European Journal of International Law Vol. 11, No.1, December, pp. 91-120.

Bakker, F.E.(2017). "Do liberal norms matter? A cross-regime experimental investigation of the normative explanation of the democratic peace thesis in China and The Netherlands" (PDF). Acta Politica. 52 (4): 521-543. doi:10.1057/s41269-016-00024. hdl:1887/74424. ISSN 0001-6810. S2CID 148403388.

Beck, N., King, G., Zeng, L. (2004). "Theory and Evidence in International Conflict: A Response to de Marchi, Gelpi, and Grynaviski" (PDF). American Political Science Review. 98 (2): 379-389. doi:10.1017/s0003055404001212. S2CID 16772841.

Bennett, S. D. (2006). "Toward a Continuous Specification of the Democracy-Autocracy Connection". International Studies Quarterly. 50 (2): 313-338. doi:10.1111/j.14682478.2006.00404.x.

Bob, Clifford. 2005. The Marketing of Rebellion: Insurgents, Media and International Activism. Cambridge: Cambridge University Press.

Bremer, S.A. (1993)."Democracy and Militarized Interstate Conflict, 1816-1965". International Interactions. 18 (3): 231-249. doi:10.1080/03050629308434806

Brinkert, Kerry. 2003. "The Convention Banning Anti-Personnel Mines: Applying the Lessons of Ottawa's Past in Order to Meet the Challenges of Ottawa's Future". Third World Quarterly, Vol.24,No.5, October, pp.781-793

Brockell, G. (2017). "The Christmas Truce miracle: Soldiers put down their guns to sing carols and drink wine". Washington Post. Retrieved 2018-08-27.

Emuedo, C.G.O (2014), Insecurity in the Niger Delta and the future of Nigeria's federalism, African Research Review 8 (34). 
Evans, A., Bartollas, C., Graham, G. and Henke, K. (2011). The Long Shadow of Emile Cailliet: Faith, Philosophy, and Theological Education. Eugene, OR: Wipf and Stock Publishers. ISBN 9781610971126.

Forster, R. A. (2019). "Ceasefires", in Romaniuk, Scott; Thapa, Manish; Marton, Péter (eds.), The Palgrave Encyclopedia of Global Security Studies, Cham: Springer International Publishing, pp. 1-8, doi:10.1007/978-3-319-74336-3_8-2, ISBN 978-3-319-74336-3

Fortna, V. (2018). 'Peace time : cease-fire agreements and the durability of peace'. ISBN 978-0691-18795-2. OCLC 1044838807.

Graham,C.(2009). Peacebuilding alum talks practical app of nonviolence Archived 2009-10-28 at the Wayback Machine, Augusta Free Press, October 26, 2009.

Hay, R. (1990). Humanitarian ceasefires : an examination of their potential contribution to the resolution of conflict. L'Institut. ISBN 0-662-18140-9. OCLC 300422008.

Igbuzor, O. (2011). Peace and Security Education: A Critical Factor for Sustainable Peace and National Development, International Journal of Peace and Development Studies Vol. 2(1), 1-7, January.

Imhonopi, D. and Urim, U. M. (2012). The Spectre of Terrorism and Nigeria's Industrial Development: A Multi-Stakeholder Imperative. The paper was prepared for the Nigerian Anthropological Summit.

Ives, S. (2001). "No Fear". Palo Alto College. Archived from the original on 20 July 2008. Retrieved 2009-05-17.

James, L. B. (1989). The Strategist of the 1960s Civil Rights Movement" by Randy Kryn, a paper in David Garrow's 1989 book We Shall Overcome Volume II, Carlson Publishing Company

Lester, R. K., and Jennifer, E. T. (1999). Encyclopedia of Violence, Peace, and Conflict, p.557, 1999. "In the West, nonviolence is well recognized for its tactical, strategic, or political aspects. It is seen as a powerful tool for redressing social inequality."

Kurlansky, M. (2008). Nonviolence: The History of a Dangerous Idea, Foreword by Dalai Lama, p. 5-6, Modern Library (April 8, 2008), ISBN 0-8129-7447-6 "Advocates of nonviolence - dangerous people - have been there throughout history, questioning the greatness of Caesar and Napoleon and the Founding Fathers and Roosevelt and Churchill."

Pandey, J. (1998), Gandhi and 21st Century, p. 50, ISBN 978-81-7022-672-7

Paine, T. (1945). “Common Sense.” 2nd Ed. Rowman and Littlefield Publishers.

Peace Direct Annual Report, 2019.

Peace Direct Annual Report, 2018.

Research Survey, 2020 
Roberts, A. (2009). Introduction, in Adam Roberts and Timothy Garton Ash (eds.), Civil Resistance and Power Politics: The Experience of Non-violent Action from Gandhi to the Present, Oxford University Press, 2009 pp. 3 and 13-20.

Ronald, B. A. and Neil, T. (1999). Looking Out/Looking In: Interpersonal Communication, 9th ed. Harcourt Brace College Publishers, p. 416, 1999. "In the twentieth century, nonviolence proved to be a powerful tool for political change."

Sagård, T. (2019). Causes of Ceasefire Failure: A survival analysis, 1989-2017 (PDF). Oslo: Peace Research Institute Oslo.

Sosnowski, M. (2020). "Ceasefires as violent state-building: local truce and reconciliation agreements in the Syrian civil war". Conflict, Security \& Development. 20 (2): 273292. doi:10.1080/14678802.2019.1679561. ISSN 1467-8802. S2CID 213876558.

Stanley, M. B. and Richard, S. (2005). "World History Ancient Civilizations ", page 154. Holt, Rinhart and Winston, 2005.

Uriel, A. (2015). Goldman, Ogen (2015). "The Domestic Democratic Peace in the Middle East" (PDF). International Journal of Conflict and Violence. 9 (5). Archived (pdf) from the original on October 19, 2015.

Wilson, R. (2016). Cultural Heritage of the Great War in Britain. Oxon: Routledge. p. 74. ISBN 9781409445739. 